\title{
昆虫与栋树的相互关系及其对栎林更新的影响
}

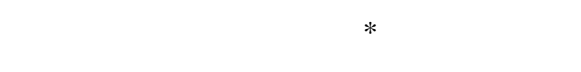

(中国科学院动物研究所, 北京 100080)

摘要: 本文概述了昆虫和栎树的相互关系以及栎林种群更新研究的进展, 从叶片和栎实两个方面分别分析昆虫对 栋树的危害、栎树对昆虫的防御以及柇林种群更新中的问题等。(1) 危害栎树的昆虫种类丰富, 它们以取食叶片 和栋实为主, 昆虫的寄生几乎使栎实完全失去活力; (2) 栋树的防御效应能影响昆虫啃食叶片的程度, 被昆虫寄生 的栎实提前下落以及栎实产量周期性的大小年变化, 能降低昆虫寄生和取食栎实所带来的损失; (3) 昆虫啃食叶 片降低柇树的能量利用和营养物质咜存, 昆虫对柇实的寄生和取食给柇树的种子库及苗库带来压力, 直接影响到 栎林的种群更新。此外, 昆虫对柇实的寄生也会影响脊椎动物搬运柇实时的选择取向, 间接控制栎实扩散, 进而影 响栋树的种群更新。

关键词：昆虫，栎树，叶片，栎实，更新

中图分类号: Q948.12+2.5 文献标识码:A 文章编号 : 1005-0094(2002) 02-0225-07

\section{Interactions of insects and oak trees and their impacts on the regeneration of oakwoods}

YU Xiao-Dong , ZHOU Hong-Zhang ${ }^{*}$, LUO Tian-Hong Institute of Zoology, Chinese Academy of Sciences, Beijing 100080

\begin{abstract}
This paper reviews the evidence for interactions between insects and oak trees, and shows how these interactions influence oakwood regeneration. First, there are abundant insect species and individuals feeding on leaves and acorns, and insect infestations are nearly always lethal to acorns. Second, quantitative defense effects may be the main strategy that oak trees use to reduce herbivory. And early fall of infested acorns and periodic synchronous mast seeding may be a result of long-term evolution in oak trees for defense against insect infestation. Third, defoliation by insect herbivores reduces energy and nutrients required for oakwood regeneration. Insect infestation decreases acorn number and seedlings in woods. Moreover, preference of sound or infested acorns by vertebrates may decrease or increase the number of potential seedlings, resulting in unexpected effects on oakwood regeneration.
\end{abstract}

Key words : insects, oak tree (Quercus) , leaves, acorns , regeneration

栎属 ( Quercus) 约 300 种, 在世界上分布极为广 泛, 不仅是亚热带常绿阔叶林的主要建群种,也是温 带落叶阔叶林的优势种之一（陈焕镛，黄成就， 1998 )。由于其木材和栎实在环境保护和经济开发 利用中具有重要地位,栎属在世界范围内得到了广 泛研究。Watt 早在 1919 年就对英国本土的栎林自 然更新失败的原因进行过详细的研究 (Watt, 1919) :Jones 也于 1959 年对英国的主要栎树 Q. ro- bur 和 Q. petraea 进行了详尽的综合研究 (Jones, 1959)。

栎树上生活着许多取食叶片的植食性昆虫 ( Raupp \& Denno , 1983 ; Hrubik \& Pozgaj, 1988 ; Skuhravy et al. , 1998) ，栎实由于富含淀粉等营养物 质(刘延兰等,1984)，也往往成为动物优先取食的 对象。因此, 昆虫寄生和取食在柇属植物中非常普 遍, 在植物的茎、叶、花及果实上很容易发现昆虫的

基金项目 : 国家自然科学基金重大项目 (39893360)、国家重点基础研究发展规划项目（G2000046801) 和中国科学院知识创新工程领域前沿项 目 
痕迹，在种子萌发、生长、开花和结果的各个阶段都 有昆虫的危害 ( Jones, 1959; Scutareanu \& Roques, 1993 ; Skuhravy et al. ,1998)。考虑到昆虫危害栎树 的主要部位为叶片和栋实, 因此我们以这两方面为 重点，从昆虫对柇树的危害、柇树对这种危害可能产 生的防御机制以及昆虫在栎树种群更新中的作用等 方面，探讨昆虫与栋树间的相互关系。

\section{1 昆虫对栎树的危害}

危害楿树的昆虫种类非常丰富。Jones (1959) 曾研究了英国的 2 种柇树, 发现危害栎树的昆虫和 蜱螨共 6 目 49 科 220 余种。Southwood (1961) 在研 究昆虫寄生种类与植物历史的关系时，统计英国本 土柇树上的昆虫多达 284 种。Scutareanu \& Roques (1993) 于 1979 1988 年间, 在罗马尼亚观察 11 种 栎属植物的雌雄花和栎实, 共发现 6 科 20 种昆虫， 其中危害雄花的有 9 种, 危害雌花的有 5 种, 危害柇 实的有 7 种。Hrubik \& Pozgaj (1988) 于 1985 1986 年间, 对斯洛伐克本土的 9 种栎树进行研究, 共发现 5 目 15 科 46 种昆虫危害柇树。Skuhravy et al. (1998)于 $1987 \sim 1992$ 年间, 在斯洛伐克根据昆虫 对栎树枝叶的危害状 (虫瘦、潜道、被啃食的树叶) 调查了危害 9 种柇树的昆虫类群组成, 共发现 5 目 78 种。于晓东等 $(2001 \mathrm{a}, \mathrm{b})$ 于 $1998 \sim 2000$ 年间对 北京东灵山区辽东栎林的研究发现, 共有 5 目 15 科 20 余种昆虫危害辽东栎的叶片和栎实。

综合这些研究可以发现，与柇树相关的昆虫主 要包含 7 目, 分别为鳞翅目 (Lepidoptera)、鞘翅目 (Coleoptera)、双翅目 (Diptera)、膜翅目 (Hymenoptera)、半翅目 (Hemiptera)、同翅目 (Homoptera)、缨 翅目 (Thysanoptera)。其中鳞翅目的卷蛾科 (Tortricidae)、麦蛾科 (Gelechiidae)、细蛾科 (Gracillariidae)、冠潜蛾科 (Tischeriidae)、微蛾科 (Nepticulidae)、夜蛾科 (Noctuidae)、蛽蛾科 (Pyralidae)、毒蛾 科 (Lymantriidae)、尺蛾科 (Geometridae) 和鞘蛾科 (Coleophoridae); 膜翅目的㾉蜂科 (Cynipidae) 和叶 蜂科 (Tenthredinidae); 鞘翅目的象甲科 (Curculionidae) 和叶甲科 (Chrysomelidae);双翅目的瘦蚊科 (Cecidomyiidae); 同翅目的蚜总科 (Aphidoidea)、叶 蝉科 (Jassidae) 和蚧科 (Coccidae); 半翅目的蝽科 ( Pentatomidae) ,为种类丰富和危害程度严重的昆虫 类群。
昆虫取食柇树叶片所造成的危害通常不是很严 重, 但在植食性昆虫 (例如蛾类幼虫) 密度很高时可 以将叶片完全啃食, 造成幼苗或幼树死亡, 从而引起 严重的危害甚至灾难 (Watt, 1919; Carlisle et al. , 1966 ; Landsberg \& Ohmart, 1989 ; Humphrey \& Swaine, 1997)。除了对幼苗或幼树的危害外, 昆虫 对成林叶片的取食也同样能降低其生物量, 如栎黄 条大蝅蛾 (Anisota senatoria) 在叶生长期末对 Virginia 东南部的柇树树叶的连续啃食, 显著地降低了栎 树的活力和生长速度, 甚至引起某些柇树的死亡 (Coffelt et al. ,1993)。Brooks (1994) 也指出, 林内 的柇树生长和死亡模式与昆虫的啃食密切相关。 Marquis \& Whelan ( 1994 ) 在讨论鸟、昆虫与柇树生 长的关系时证实，鸟类对食叶昆虫的捕食，可以大大 降低柇树所受的损失。而由于北美捕食昆虫的鸟类 种群数量逐年降低,已影响到柇树的正常生长。

昆虫对栋实的危害非常普遍, 受到昆虫寄生的 栎实基本上失去活力, 发芽率和成熟率显著降低 ( Jones , 1959 ; Oliver \& Chapin, 1984 ; Andersson, 1992 ; Zhou \& Yu，2000; 于晓东等, 2001b)。 Q. agrifolia栎实内的寄生昆虫主要为美国楱实象 (Curculio occidentis) 和榛小卷蛾 (Cydia latiferrea), 寄生率达 38\% (Lewis，1992）；枹柇（Q. serrata）的柇 实寄生者有柞栎象 (Curculio dentipes)、Poecilips cardamomi、Mechoris ursulus、Kobuzo retictirostris 等 ( Fujii，1993）夏栋 ( Q . robur ) 林内危害栋实的 2 种主 要昆虫为係㾇蜂 (Andricus quercuscalicis) 和欧洲榛实 象 (Curculio glandium), 在某些年内造成的损失达 $30 \% \sim 90 \%$, 可以使一棵树的栎实产量在 0 100\% 之间变化 (Crawley \& Long, 1995)。此外, 其他柇属 树种的柇实也常被昆虫侵害, 如象虫属(Curculio)、 瘦蚊属(Clinodiplosis)、无翅瘰蜂属( Callirhytis)、小 卷蛾属 (Cydia) 等, 寄生率可以高达 80\% 甚至 $90 \%$ ( Gurnell, 1993 ;Scutareanu \& Roques ,1993;Kelbel , 1996 ; Skuhravy et al. ,1998)。在我国, 辽东栋 ( Q. liaotungensis)、蒙古栋 ( Q. mongolica)、麻栋 ( Q. acutissima 、犐栋 ( Q. aliena $)$ 等常见落叶柇的栋实的昆虫 寄生程度也很高, 寄生昆虫有柞柇象、麻栎象( Cur culio robustus)、榛实象 (Curculio dieckmanni)、剪枝柇 实象 (Cyllorhynchites ursulus)、栗黑小卷蛾 (Cydia glandicolana)、栗白小卷蛾 (Cydia kurokoi) 等, 对柇 实的产量影响很大 ( 赵养昌, 陈元清, 1980; 黄孝运, 
李广武, 1991; 于诚铭, 1991; 刘振陆, 1991; 方德齐, 王桂欣，1991; 王化德，李桂和，1991;于晓东等， $2001 b$ )。

\section{2 栎树对昆虫危害可能产生的防御机制}

\section{1 叶片的防御机制}

植物与昆虫等植食动物之间的关系研究在过去 几十年内得到很大的发展, 尤其是量化防御理论 (Quantitative Defense Theory) 得到很深入的研究, 强 调受啃食植物组织成分变化 (尤其是单宁和蛋白质 的含量) 与昆虫取食叶片程度之间的相关关系 ( Coley , 1980 ; Bernays , 1981 ; Faeth , 1985 ; Schultz , 1988 ; Karban et al. , 1997)。Feeny (1970)指出， 柇树叶内单宁含量的季节性变化与植食性昆虫种群 数量的季节性波动密切相关, 可能是一种对付昆虫 危害的防御机制。Rossiter et al. (1988) 在研究舞毒 蛾 (Lymantria dispar) 习性时发现, 舞毒蛾的产卵量 与夏柇叶子的季节性酚类变化以及由危害引起叶片 组织内酚类或非酚类物质的变化密切相关, 由于叶 片受到的危害而引起的叶片内酚类物质凝集的差异 可以影响到舞毒蛾的生育能力和产卵总量。同样, Schultz \& Baldwin( 1982 ) 发现，如果夏栋在前一年叶 片受到舞毒蛾的侵食，其第二年的叶片中可水解的 单宁含量、单宁系数、酚类物质总量及叶片的厚度韧 度均明显高于前一年未受危害的树木，这些变化会 影响昆虫幼虫的生长发育和种群大爆发的进程。 Appel \& Schultz (1994) 认为, 柇树叶片内的单宁能 降低舞毒蛾体内重要化学成分的合成, 从而有效地 抑制舞毒蛾的危害。Wold \& Marquis (1997) 研究发 现:Quercus alba 完整的树叶比受危害的树叶的蛋白 含量高, 植食性昆虫密度更高, 许多植食性昆虫经常 避免取食危害过的叶片, 这种习性导致取食危害范 围的分散。因此他们断定, 被昆虫危害过的叶片质 量变化能降低该植株以后受到危害的可能性。

但目前也有许多实验否认植物存在诱导防御 (induced defense), 认为这种表面上的防御或抵御 昆虫侵食的现象可能是植物其他反应的一种产物。 Faeth (1985) 认为昆虫对叶片的取食行为并不是由 植物体内次生化学物质和营养成分的季节性变化单 独决定的, 单宁和蛋白质的季节性变化与昆虫取食 行为不完全一致, 其他因素如温度、昆虫生活史或树 叶被损害后产生的化学或物理变化都可能影响取食
行为。Kleiner \& Montgomery (1994) 通过实验提出 舞毒蛾的数量爆发与柇树生长环境的湿度密切相 关, 而与叶片的质量 (主要指单宁和蛋白质含量) 无 关。Hunter \& Schultz (1995) 也认为, 栎树的所谓诱 导防御机制并不是积极的防御，而是因为营养匮乏， 补充足够的肥料就会阻止防御反应的产生。Mopper \& Simberloff (1995) 通过对 Florida 北部生长的 Quercus geminata 观察, 认为潜叶蛾 (Stilbosis quadricustatella) 优先选择晚萌发的叶片产卵, 因而决定其危害 程度的是叶片萌发的早晚, 与叶片所含的次生化学 物质含量无关。

此外, 柇树树叶成熟前调落也被认为是一种诱 导防御机制, 与潜叶昆虫的活动相关。但从目前对 Quercus nigra 的研究来看, 树叶的调落通常发生在 潜叶昆虫成功离开或已经死于其他原因之后，所以 成熟前调落仅仅是树叶生理破坏的结果, 而不能归 因于寄主植物调节危害昆虫种群的诱导机制 ( Stiling \& Simberloff , 1989)。

\section{2 栋实的防御机制}

从表面上看，栋实对昆虫的取食没有有效的防 御方式。但 Gurnell(1993) 观察到, 某些栎树栎实被 昆虫感染后会提前下落。Boucher \& Sork (1979) 也 发现受昆虫感染的核桃 (Carya glabra) 有成熟前下 落的现象, 被昆虫寄生的种子在发育后期停止生长, 其重量比有活力的种子轻许多，从而避免资源的浪 费。Weckerly et al. (1989a) 通过研究象虫幼虫、柇 实内单宁含量和种子萌发之间的关系发现, 柇实内 单宁含量降低了Quercus alba 和 Q. rubra 种子被象 虫取食的数量, 提高了栎林内栎实萌发的成功率。 此外, Steele et al. (1993) 通过实验发现, 栎树 ( Quercus phellos, Q. rubra, Q. laevis, Q. nigra, Q. palustris) 已经很好地适应了栎实被动物取食, 通过栎实 基部单宁的高密度凝聚, 保护胚部不受昆虫或脊椎 动物侵害。Oliver \& Chapin(1984), 以及 Zhou \& Yu （2000）也发现，虽然昆虫对柇实的寄生会降低其发 芽率, 但并非是绝对致命的, 仍有相当数量被昆虫寄 生的栎实能够发芽。Andersson (1992) 认为, 在柇实 产量很低的年份, 这些被昆虫寄生的栎实的萌发对 栎林更新的贡献可能就显得十分重要。然而从以往 实验来看, 昆虫取食的栎实即使发芽率很高, 但由于 这种栋实易受病菌感染, 在冬季容易腐烂, 成苗率很 难提高, 因而不能为种群更新作出太大贡献 ( Jones, 
1959)。

此外,栎树栎实的周期性大年理论可能揭示了 另一种防御机制 ( Janzen,1971; W Waller, 1979,1993; Silvertown 1980; Fenner, 1991; ;ork et al. 1993; ;oenig et al. ,1994)。这种理论是建立在多年生植物种 实产量周期性变化基础上，与 捕食者饱足 (Predator satiation) " 现象密切相关 (Janzen，1971)，即栎树通 过种子产量周期性的变化改变捕食者的饥饿或饱足 程度, 在某一年内暂时满足动物的食物需要, 使避过 动物捕食的种子得以幸存, 以提高在种子高峰后的 年份内新生苗出现的概率。这个理论目前已被广泛 接受, 被认为是植物抵御昆虫寄生的最好方式, 即在 种子雨小年寄生率高, 在种子雨大年寄生率低, 这是 昆虫与栎树之间长期协同进化的结果, 但目前比较 合理的实验证明很少 ( Crawley \& Long ,1995) ,需要 更多长期有效的监测和实验来进一步证实。

\section{3 昆虫在栎树种群更新中的作用}

\section{1 植食性昆虫取食叶片}

以往的研究证明, 植食性昆虫取食叶片对栎树 的更新只有负面影响，昆虫通过降低生物量，破坏幼 苗 影响到栎树生长和种群更新（Watt，1919；Coffelt et al. , 1993 ; Brooks , 1994 ; Marquis \& Whelan , 1994 ; Humphrey \& Swaine , 1997 )。但近来也有人 认为, 如果啃食叶片的程度和危害面积在树木容忍 的程度内，昆虫的啃食实际上加速了叶片的分解效 率, 使营养物质提前加入到森林生态系统中, 有利于 森林的生长和更新 (Belovsky \& Slade , 2000 ; Stadler et al. ,2001)。

\section{2 昆虫对栎实寄生}

与叶片相比, 栎实在栎林更新中的作用和地位 更重要。如图 1 所示, 昆虫可以从两条途径影响柇 树的种群更新 :1) 由于栎实富含营养, 吸引着大量 昆虫取食, 导致栎实死亡, 直接威胁栎林未来苗库的 存活概率和种群的自然更新 2) 由于栎树种群主要 通过脊椎动物搬运种子完成种群扩散和更新 ( Howe \& Smallwood , 1982 ; Smith \& Reichman , 1984 ; Jensen \& Nielsen , 1986 ; Kikuzawa , 1988 ; Scarlett \& Smith , 1991 ; Crawley , 1992 ; Reader , 1993 ; Chambers \& MacMahon , 1994 ; Kollmann \& Schill , 1996 ; 王巍，马克平，1999），栎实内的昆虫幼虫可能影响 脊椎动物的搬运选择，间接影响了栎树的种群扩散
和更新 (Johnson et al. , 1993 ; Dixon et al. , 1997)。 对其他树种的研究也表明, 种实内的昆虫寄生不仅 影响到种实本身的命运 (发育、成熟、发芽), 而且影 响到脊椎动物搬运取食果实的选择倾向，决定了植 物种子扩散和新生苗萌发的机会, 体现了脊椎动物、 昆虫与植物之间的协同进化关系 (Manzur \& Courtney , 1984 ; Valburg , 1992)。

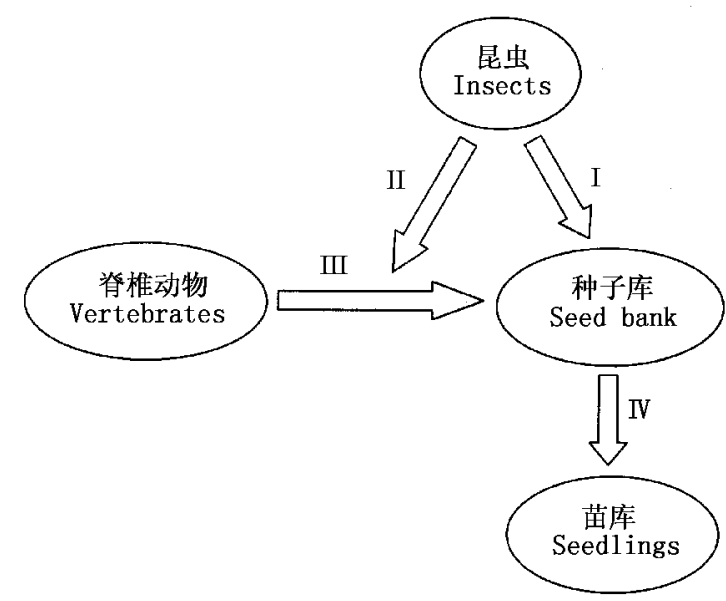

图 1 昆虫、脊椎动物和栎实三者之间的关系

Fig. 1 Relationships among insects, vertebrates and acorns I. 昆虫对种子寄生 Insect infestation; II. 栎实内昆虫寄生对脊椎动 物取食搬运种子的影响 Insect infestation affects the choice of vertebrates in acorn removing; III. 脊椎动物 (鸟兽) 取食搬运栎实, 同时对 种子扩散有贡献 Vertebrate removing helps acorn dispersal and seedling establishment ; IV. 种子萌发成苗 Acorn germinating to form seedlings

由于昆虫可以通过上述两种途径决定栎实的命 运，根据脊椎动物取食和搬运栎实时的选择取向，昆 虫对栎实的命运影响可以分以下 3 种情况 :1) 脊椎 动物对栎实没有选择倾向, 昆虫的影响完全依赖于 寄生率的大小 2) 脊椎动物对未被昆虫寄生的栎实 有选择倾向, 昆虫的影响与脊椎动物的选择取向有 关, 种子库压力加大 3) 脊椎动物对昆虫寄生的栎 实有选择倾向, 昆虫的影响与脊椎动物的选择取向 有关, 种子库的压力减轻。

3.2.1 脊椎动物对种子没有选择倾向 昆虫对栎 林更新的影响局限于昆虫寄生自身的作用, 与脊椎 动物之间没有交叉影响, 昆虫通过控制种子的死亡 率、成熟率和发芽率影响种群更新 (Crawley \& Long, 1995 ;Zhou \& Yu ,2000)。Semel \& Andersen(1988) 通过野外实验发现, 白足鼠 (Peromyscus leucopus) 取 食栎实时,并不受昆虫寄生种子比例的影响。Horton \& Wright (1944) 及 Weckerly et al. (1989b) 在研 究暗足林鼠 (Neotoma fuscipes) 和北美灰松鼠 (Sciurus carolinesis) 对栎实的取食搬运时也发现，动物并 
不把有无昆虫寄生作为选择栎实的标准。可见, 昆 虫对栎林种子库的危害主要取决于其寄生率的高 低,昆虫寄生率的变化影响未来苗库的大小。

3.2.2 脊椎动物对好种子有选择倾向 昆虫与脊 椎动物之间有交叉作用, 存在着较强的竞争, 脊椎动 物对栎实的搬运加大了种子库压力, 但同时有利于 种子扩散。Bossema (1979) 和 Dixon et al. (1997) 分 别通过野外观察和室内行为选择实验发现, 冠蓝鸦 (Cyanocitta cristata) 能通过视觉或栎实密度不同区 分好栎实和被昆虫寄生的栎实, 有优先选择好栎实 的倾向。

如果脊椎动物选择好栎实, 在搬运取食时就需 要对栎实进行分类挑选, 这必然要消耗能量。昆虫 寄生率越高, 动物的种子选择分类越困难, 选错的机 会越高，付出的代价就越高。Dixon et al. (1997) 证 实，昆虫对栎实的寄生影响了冠蓝鸦和栎树的关系， 降低了冠蓝鸦所能消耗和扩散栎实的潜在数量。山 楂 (Crataegus monogyna) 种子的传播者 [ 主要为乌鸫 ( Turdus merula) ] 优先取食好的果实, 但在昆虫寄生 率很高的情况下, 因为辨别错误而增加了近 $15 \%$ 的 好果实未被搬运扩散, 使山楂受到的损失比昆虫寄 生本身危害更大(Manzur \& Courtney，1984)。

因此，在昆虫寄生率很高的情况下，脊椎动物对 好栎实的优先选择将不利于好栋实的保存, 因而对 种子库取食压力加大, 使出苗机会大大降低。但同 时, 动物搬运又是柇树栎实扩散的主要动力, 可能对 种群的扩散有贡献。

3.2.3 脊椎动物对昆虫寄生种子有选择倾向 昆 虫与脊椎动物之间有交叉作用, 减轻了种子库压力， 提高了新生苗的出现概率, 但不利于栋实扩散。在 栎实的研究中, 尚未发现这种现象。在对一种浆果 (Acnistus arborescens) 的类似研究中, 证实脊椎动物 有选择昆虫寄生果实的现象，因为果实被昆虫寄生， 脊椎动物搬运果实数量增大, 提高了种群扩散 ( Valburg , 1992)。

Johnson et al. (1993) 通过分析食物成分发现, 栎实内虽富含淀粉，但缺乏蛋白质，同时也含有不利 于动物消化的次生化合物一一单宁。松鸦在取食柇 实时只有补充一定量的蛋白质才能平衡栎实内单宁 的危害, 而寄生于栎实内的昆虫幼虫 (主要为象虫 幼虫, Curculio sp. ) 富含蛋白质。因此提出假设:动 物在取食栎实时会优先选择被昆虫寄生的栎实，从
而间接使好栎实得以保存。因此低水平和中等水平 的昆虫寄生率将有利于栎树种群最终的恢复和更 新。但后来 Dixon et al. (1997) 的实验没有证实这 一假设: 冠蓝鸦在选择栎实时, 没有优先选择昆虫寄 生的栋实,而是优先取食好栋实。Dixon et al. (1997) 认为, 昆虫寄生的栎实虽然包含了动物蛋白 (昆虫幼虫), 但同时充满了许多昆虫幼虫的粪便和 渣滓, 在某种程度上提高了单宁含量, 口感不好, 能 量方面也有一定损失, 而且幼虫所含的蛋白质量远 远低于冠蓝鸦所需要补充的量, 这些都不利于冠蓝 鸦取食。Semel \& Andersen ( 1988 ) 通过实验也证 实, 动物打开含有幼虫或渣滓的柇实所消耗的平均 能量超过了他们所能获得的幼虫蛋白能量, 在理论 上没有意义。

\section{4 小结}

综上所述, 昆虫与栎树的关系十分密切, 昆虫对 栎树叶片和栎实的取食非常普遍, 在危害程度可以 容忍的情况下, 柇树维持了大量昆虫物种的生存。 但当昆虫啃食叶片比较严重, 以及昆虫对栎实寄生 率较高的情况下, 会危及到栎树的生长。栎树抵御 昆虫取食叶片的方式主要表现为叶片内次生化合物 合成增多, 叶片增厚和变硬, 口感变差, 并且可以在 一定程度上影响植食性昆虫的生活史, 降低其种群 密度。栎树抵御昆虫寄生栎实的方法主要为: 使被 昆虫寄生的栎实提前下落, 避免受到更多损失; 通过 栎实产量周期性的大小年变化, 调节昆虫寄生率的 高低 (捕食者饱足假说), 调节昆虫种群变化。植食 性昆虫在密度很高的情况下, 可降低柇树的生物量, 危及到栎树的生长, 对栎林更新不利。昆虫对栎实 的寄生降低种子的成熟率和发芽率, 影响到种子库 和苗库的大小。此外, 脊椎动物搬运栎实是种子扩 散和栎树种群更新的主要途径, 栎实被昆虫寄生后， 可能会影响到脊椎动物搬运栎实时的选择倾向和效 率, 因此, 昆虫寄生又可以间接影响到栎树的种群更 新。

致谢: 中科院植物所的高贤明博士、王巍博士、李庆 康博士和间文杰女士提供部分相关文献, 特此表示 感谢。 


\section{参考文献}

陈焕镛, 黄成就, 1998. 中国植物志 (第 22 卷). 北京: 科学出 版社

方德齐, 王桂欣, 1991. 麻栎象 Curculio robustus Roelofs. 见: 萧刚柔 (主编): 中国森林昆虫(第 2 版). 北京: 中国林 业出版社, $578 \sim 579$

黄孝运, 李广武, 1991. 柞栎象 Curculio dentipes Roelofs. 见: 萧刚柔 (主编): 中国森林昆虫(第 2 版). 北京: 中国林 业出版社, $573 \sim 575$

刘延兰, 杨涵贞, 柴慧瑛, 1984. 中国栎属柇实化学组成的研 究(一): 十四种落叶栎类. 北京林学院学报, 4: $51 \sim 54$

刘振陆, 1991. 剪枝栎实象Cyllorhynchites ursulus (Roelofs). 见: 萧刚柔 (主编): 中国森林昆虫 (第 2 版). 北京: 中国 林业出版社, $579 \sim 580$

王化德, 李桂和, 1991. 栗黑小卷蛾 Cydia glandicolana (Danil). 见: 萧刚柔(主编): 中国森林昆虫(第 2 版). 北京: 中国林业出版社, 817

王巍, 马克平, 1999. 岩松鼠和松鸦对辽东栎坚果的捕食和 传播. 植物学报, 41 (10): 1142 1144

于诚铭, 1991. 榛实象 Curculio dieckmanni (Faust). 见: 萧刚 柔 (主编): 中国森林昆虫 (第 2 版). 北京: 中国林业出 版社, $575 \sim 576$

于晓东, 周红章, 罗天宏, $2001 \mathrm{a}$. 辽东栎叶片昆虫取食形状 多样性及其变化模式. 植物生态学报, 25 (5): 553 560 于晓东, 周红章, 罗天宏, 何君舰, 张知彬, $2001 \mathrm{~b}$. 昆虫寄生 对辽东栎 (Quercus liaotungensis) 种子命运的影响. 昆虫 学报, 44 (4) : 518 524

赵养昌, 陈元清, 1980. 中国经济昆虫志 [ 第二十册: 鞘翅目 象虫科 (一)]. 北京: 科学出版社, $159 \sim 164$

Andersson C, 1992. The effect of weevil and fungal attacks on the germination of Quercus robur acorns. Forest Ecology and Management, 50: $247 \sim 251$

Appel H M and J C Schultz, 1994. Oak tannins reduce effectiveness of Thuricide (Bacillus thuringiensis) in the Gypsy Moth (Lepidoptera: Lymantriidae). Journal of Economic Entomology, 87 (6) : $1736 \sim 1742$

Belovsky G E and J B Slade, 2000. Insect herbivory accelerates nutrient cycling and increases plant production. Proceedings of Natural Academy of Sciences, USA, 97 (26) : 14412 $\sim 14417$

Bernays E A, 1981. Plant tannins and insect herbivores: an appraisal. Ecological Entomology, 6: $353 \sim 360$

Bossema I, 1979. Jays and oaks: an eco-ethological study of a symbiosis. Behaviour, 70: $1 \sim 117$

Boucher D H and V L Sork, 1979. Early drop of nuts in response to insect infestation. Oikos, 33: $440 \sim 443$

Brooks R T, 1994. A regional-scale survey and analysis of forest growth and mortality as affected by site and stand factors and acidic deposition. Forest Science, 40 (3) : $543 \sim 557$

Carlisle A, A H F Brown and E J White, 1966. Litter fall, leaf production and the effects of defoliation by Tortrix viridana in a sessile oak (Quercus petraea) woodland. Journal of Ecology, 54: $65 \sim 85$

Chambers J C and J A MacMahon, 1994. A day in the life of a seed: movements and fates of seeds and their implications for natural and managed systems. Annual Review of Ecology and Systematics, 25: $263 \sim 292$

Coffelt M A, P B Schultz and D D Wolf, 1993. Impact of late- season orange striped oakworm (Lepidoptera: Saturniidae) defoliation on oak growth and vigor. Environmental Entomology, 22 (6) : $1318 \sim 1324$

Coley P D, 1980. Effects of leaf age and plant life history patterns on herbivory. Nature, 284: $545 \sim 546$

Crawley M J, 1992. Seed predator and plant population dynamics. In: Fenner M (eds.), Seeds: the Ecology of Regeneration in Plant Communities. Wallingford: CAB International, $157 \sim 191$

Crawley M J and C R Long, 1995. Alternate bearing, predator satiation and seedling recruitment in Quercus robur L. Journal of Ecology, 83: $683 \sim 696$

Dixon M D, W C Johnson and C S Adkisson, 1997. Effects of weevil larvae on acorn use by blue jays. Oecologia, 111: $201 \sim 208$

Faeth S H, 1985. Quantitative defense theory and patterns of feeding by oak insects. Oecologia, 68: $34 \sim 40$

Feeny P, 1970. Seasonal changes in oak leaf tannins and nutrients as a cause of spring feeding by winter moth caterpillars. Ecology, 51 (4): $565 \sim 581$

Fenner M, 1991. Irregular seed crops in forest trees. Quarterly Journal of Forestry, 85: $166 \sim 172$

Fujii S, 1993. Studies on acorn production and seed predation in Quercus serrata: growth, falling phenology, estimation of production, and insect seed predators. Bulletin of the Osaka Museum of Natural History, 47: 1 17

Gurnell J, 1993. Tree seed production and food conditions for rodents in an oak wood in southern England. Forestry (Eynsham), 66 (3) : $291 \sim 315$

Horton J S and J T Wright, 1944. The wood rat as an ecological factor in southern California watersheds. Ecology, 25 (3) : $341 \sim 351$

Howe H F and J Smallwood, 1982. Ecology of seed dispersal. Annual Review of Ecology and Systematics, 13: $201 \sim 228$

Hrubik P and J Pozgaj, 1988. Entomofauna of autochthonous oak trees in the Cifare Experimental Quercetarium (Czechoslovakia). Lesnictvi (Prague), 34 (12) : $1079 \sim 1092$

Humphrey J W and M D Swaine, 1997. Factors affecting the natural regeneration of Quercus in Scottish oakwoods. II. Insect defoliation of trees and seedlings. Journal of Applied Ecology, 34: $585 \sim 593$

Hunter M D and J C Schultz, 1995. Fertilization mitigates chemical induction and herbivore responses within damaged oak trees. Ecology, 76 (4) : $1226 \sim 1232$

Janzen D H, 1971. Seed predation by animals. Annual Review of Ecology and Systematics, 2: $465 \sim 492$

Jensen T S and O F Nielsen, 1986. Rodents as seed dispersers in a heath: oak wood succession. Oecologia, 70: 214 221

Johnson W C, L Thomas and C S Adkisson, 1993. Dietary circumvention of acorn tannins by blue jays: implications for oak demography. Oecologia, 94: $159 \sim 164$

Jones E W, 1959. Biological flora of the British Isles: Quercus L. Journal of Ecology, 47 (1): $169 \sim 222$

Karban R, A A Agrawal and M Mangel, 1997. The benefits of induced defenses against herbivores. Ecology, 78 ( 5 ): $1351 \sim 1355$

Kelbel P, 1996. Damage to acorns by insects in Slovakia. Bio- 
logia (Bratislava), 51 (5) : $575 \sim 582$

Kikuzawa K, 1988. Dispersal of Quercus mongolica acorns in a broad-leaved deciduous forest: 2. scatterhoarding by mice. Forest Ecology and Management, 25: $9 \sim 16$

Kleiner K W and M E Montgomery, 1994. Forest stand susceptibility to the gypsy moth (Lepidoptera: Lymantriidae) : species and site effects on foliage quality to larvae. Environmental Entomology, 23 (3) : 699 711

Koenig W D, R L Mumme, W J Carmen and M T Stanback, 1994. Acorn production by oaks in central coastal California: variation within and among years. Ecology, 75 (1): $99 \sim 109$

Kollmann J and H P Schill, 1996. Spatial patterns of dispersal, seed predation and germination during colonization of abandoned grassland by Quercus petrea and Corylus avellana. Vegetatio, 125: $193 \sim 205$

Landsberg J and C Ohmart, 1989. Levels of insect defoliation in forests: patterns and concepts. Trends in Ecology and Evolution, 4 (4): $96 \sim 100$

Lewis V R, 1992. Within-tree distribution of acorns infested by Curculio occidentis (Coleoptera: Curculionidae) and Cydia latiferreana (Lepidoptera: Tortricidae) on the coast live oak. Environmental Entomology, 21 (5) : $975 \sim 982$

Manzur M I and S P Courtney, 1984. Influence of insect damage in fruits of hawthorn on bird foraging and seed dispersal.

Oikos, 43: $265 \sim 270$

Marquis R J and C J Whelan, 1994. Insectivorous birds increase growth of white oak through consumption of leaf-chewing insects. Ecology, 75 (7) : $2007 \sim 2014$

Mopper S and D Simberloff, 1995. Differential herbivory in an oak population: the role of plant phenology and insect performance. Ecology, 76 (4) : $1233 \sim 1241$

Oliver A D and J B Chapin, 1984. Curculio fulvus (Coleoptera: Curculionidae) and its effects on acorns of live oaks, Quercus virginiana Miller. Environmental Entomology, 13 (6) : $1507 \sim 1510$

Raupp M J and R F Denno, 1983. Leaf age as a predictor of herbivore distribution and abundance. In: Denno R F, M S McClure (eds.), Variable Plants and Herbivores in Natural and Managed Systems. Academic Press Inc., New York, $91 \sim 124$

Reader R J, 1993. Control of seedling emergence by ground cover and seed predation in relation to seed size for some old-field species. Journal of Ecology, 81: 169 175

Rossiter M, J C Schultz and I T Baldwin, 1988. Relationships among defoliation, red oak phenolics, and gypsy moth growth and reproduction. Ecology, 69 (1) : $267 \sim 277$

Scarlett T L and K G Smith, 1991. Acorn preference of urban blue jays (Cyanocitta cristata) during fall and spring in northwestern Arkansas. Condor, 93: $438 \sim 442$

Schultz J C, 1988. Plant responses induced by herbivores. Trends in Ecology and Evolution, 3 (2): $45 \sim 49$

Schultz J C and I T Baldwin, 1982. Oak leaf quality declines in response to defoliation by gypsy moth larvae. Science, 217: $149 \sim 151$

Scutareanu P and A Roques, 1993. Insect damage to male catkins, female flowers and acorns of Quercus spp. in Romania. Journal of Applied Entomology, 115 (4):321 328
Semel B and D C Andersen, 1988. Vulnerability of acorn weevils (Coleoptera: Curculionidae) and attractiveness of weevils and infested Quercus alba acorns to Peromyscus leucopus and Blarina brevicauda. American Midland Naturalist, 119: $385 \sim 393$

Silvertown J W, 1980. The evolutionary ecology of mast seeding in trees. Biological Journal of the Linnean Society, 14: 235 $\sim 250$

Skuhravy V, P Hrubik, M Skuhrava and J Pozgaj, 1998. Occurrence of insects associated with nine Quercus species (Fagaceae) in cultured plantations in southern Slovakia during $1987 \sim 1992$. Journal of Applied Entomology, 122 (4) : $149 \sim 155$

Smith C C and O J Reichman, 1984. The evolution of food caching by birds and mammals. Annual Review of Ecology and Systematics, 15: $329 \sim 351$

Sork V L, J Bramble and O Sexton, 1993. Ecology of mastfruiting in three species of North American deciduous oaks. Ecology, 74 (2): $528 \sim 541$

Southwood T R E, 1961. The number of species of insect associated with various trees. Journal of Animal Ecology, 30: 1 $\sim 8$

Stadler B, S Solinger and B Michalzik, 2001. Insect herbivores and the nutrient flow from the canopy to the soil in coniferous and deciduous forests. Oecologia, 126: $104 \sim 113$

Steele M A, T Knowles, K Bridle and E L Simms, 1993. Tannins and partial consumption of acorns: implications for dispersal of oaks by seed predators. American Midland Naturalist, 130: $229 \sim 238$

Stiling P and D Simberloff, 1989. Leaf abscission: induced defense against pests or response to damage? Oikos, 55 (1) : $43 \sim 49$

Valburg L K, 1992. Eating infested fruits: interactions in a plant-disperser-pest triad. Oikos, 65: $25 \sim 28$

Waller D W, 1979. Models of mast fruiting in trees. Journal of Theoretical Biology, 80: $223 \sim 232$

Waller D W, 1993. How does mast-fruiting get started? Trends in Ecology and Evolution, 8: $122 \sim 123$

Watt A S, 1919. On the causes of failure of natural regeneration in British oakwoods. Journal of Ecology, 7 (3 4) : 173 203

Weckerly F W, D W Sugg and R D Semlitsch, 1989a. Germination success of acorns (Quercus): insect predation and tannins. Canadian Journal of Forest Research, 19 (6) : 811 $\sim 815$

Weckerly F W, K E Nicholson and R D Semlitsch, 1989b. Experimental test of discrimination by squirrels for insect-infested and noninfested acorns. American Midland Naturalist, 122 (2) : $412 \sim 415$

Wold E N and R J Marquis, 1997. Induced defenses in white oak: effects on herbivores and consequences for the plant. Ecology, 78 (5) : $1356 \sim 1369$

Zhou H and X Yu, 2000. Recovery of oakwoods in North China and influence of insects. In: Vol. 5 (Part 3): Biodiversity and Dynamics of Ecosystems of North-Eastern Asia, The Proceeding of Biodiversity and Dynamics of Ecosystems in North Eurasia, IC\&G, Novosibirsk, Russia, $113 \sim 115$

(责任编辑：时意专) 